$\langle$ 症例〉

\section{内視鏡的胆囊ステント留置後に胆石 性イレウスを発症した一例}

\author{
田澤 真一*，太和田勝之，大野 力 \\ 薄井 正俊, 野本 裕正, 齋藤 博文 \\ 北和彦
}

千葉市立海浜病院 消化器内科

*Corresponding author : shinichi.tazawa24@gmail.com

〔Key Words〕胆石性イレウス, EGBS

\section{症 例}

患者：69 歳, 女性.

主訴：右季肋部痛, 嘔吐.

既往歴：胆石性胆襄炎

家族歴：特記すべき事項無し.

現病歴：平成 28 年 6 月下旬に急性胆石性胆囊炎で 当院入院. 経皮経肝胆囊ドレナージ (percutaneous transhepatic gallbladder drainage : PTGBD) は穿刺 ルート確保困難の為行えず, 内視鏡的胆囊ステント留 置術 (endoscopic gallbladder stenting : EGBS) を留置 し, 以降抗菌薬投与で胆囊炎は改善したため 7 月上旬 退院となった．本人が胆囊摘出手術を希望しなかった ため外来で経過観察の方針としていた.

平成 28 年 10 月上旬から腹部全体の疼痛, 嘔吐あり で当院を受診し, 腹部造影 CT 画像から胆石性イレウ スの診断で入院となった.

第 2 回入院時現症: 体温 $37.3^{\circ} \mathrm{C}$, 血圧 $123 / 88$ $\mathrm{mmHg}$, 脈拍 135 回/分, 腹部はやや膨満, 軟で全体に

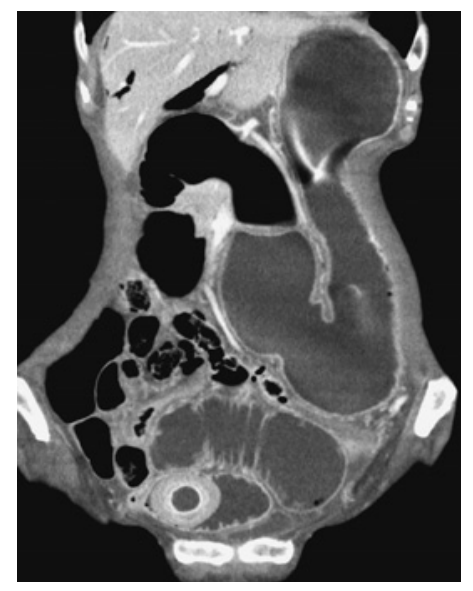

Fig. 1 Abdominal CT
圧痛を認めた．笳性防御や反跳痛などの腹膜刺激所見 は認めなかった。

第 2 回入院時検查所見 : CRP $41.18 \mathrm{mg} / \mathrm{dl}, \mathrm{WBC}$ $7400 / \mathrm{mm}^{3}$ （好中球 $93.6 \%$ ）で高度炎症を認めた。

腹部造影 CT (入院時施行)：胆囊は十二指腸と穿通 し虚脱. EGBS の内瘦ステントは胆囊から脱落し上行 結腸に移動していた。前胆囊内に存在していた結石 は回腸に嵌頓していた（Fig. 1)，嵌頓した結石より口 側の小腸で著明な拡張と nieveau を認めた.

入院後経過：内視鏡を使用して経鼻イレウス管を留 置した。 その際の内視鏡で十二指腸に穿通する胆囊内 腔を確認し得た（Fig. 2)。外科医師と相談し，当初は 自然排石を期待して保存的加療を継続した. しかし，そ の後も結石の位置は変わらず, 腹痛症状も持続してい たため第 9 病日に腹腔鏡下で小腸切開, 胆石摘出手術 を行った. 術後は肺炎などを合併し治療を要したが, 第 42 病日に退院となった。

\section{考 察}

胆石性イレウスは胆石が胆管や瘦孔を介して消化管 内に逸脱し，嵌頓することで発症する疾患で胆石症に おける本疾患の頻度は $0.5 \sim 0.7 \%$ である。好発は 70 歳代女性で嵌頓部位は回腸 (50.0\%) や空腸 (26.9\%) が 多い1)。結石の通過経路としては胆囊十二指腸瘦孔が 大多数である $(68 \%)^{2)}$. 本症例に扔いても好発条件に 合致した.

胆囊十二指腸㾞孔については，自然閉鎖が多いとす る報告もある一方 ${ }^{3}$, 胆石性イレウス再発や続発症と しての胆囊癌も報告されているため早期に閉鎖手術を 行うべきとの意見もある ${ }^{4}$.

本症例は患者希望により瘦孔形成術は施行せず，慎 重に経過観察を行っている.

本邦のガイドラインでは急性胆囊炎に対する治療の 第一選択は早期の胆囊摘出術となっている5). しかし 現実的には全ての胆囊炎患者に早期手術を行うことは

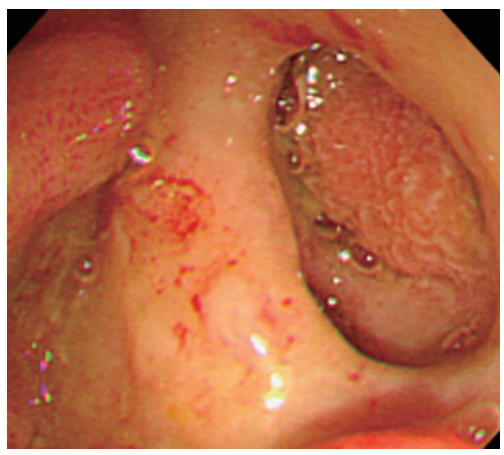

Fig. 2 Endoscope image 
困難であり，ドレナージを併用した保存的加療で改善 を図る事も経験する。非切除のまま経過を追う場合に は, 本疾患の生じる可能性も認識することが重要であ る.

\section{おわりに}

EGBS 留置中に胆石性イレウスを発症した稀な一例 を経験したので報告した.

\section{文 献}

1 ）波多野賢二, 石原敬夫, 埜口武夫, 他：胆石イレウスの 1 例一自験例を含む本邦報告 130 例の検討一. 臨床外科 54 : 2150-2154, 1993

2) Clavien PA, Richon J, Burgan S, et al : Gallstone ileus. Br J Surg $77: 737-742,1990$

3 ) 原 竜平, 坂口孝宣, 稲葉圭介, 他: 胆囊十二指腸瘦の自然 閉鎖を経過観察しえた胆石イレウスの 1 例. 日本外科連会誌 $36: 72-78,2011$

4 ）春田周宇介, 橋本雅司, 松田正道, 他：胆石イレウス術後 3 年目に胆囊癌を発症した 1 例. 日本臨床外科学会 $10 ： 1489$ 1493,1984

5 ) 日本消化器病学会 : 胆石症診療ガイドライン 2016 (改訂第 2 版), 2016

\section{Development of gallstone ileus with duodenal fistula following endoscopic gallbladder stenting:} A case report

\author{
Shinichi Tazawa*, Katsunobu Tawada \\ Riki Oono, Masatoshi Usui \\ Hiromasa Nomoto, Hirofumi Saito \\ Kazuhiko Kita
}

Although the efficacy of long-term indwelling endoscopic gallbladder stent (EGBS) has been established in recent years, we report here a case of gallstone ileus that developed under the presence of indwelling EGBS. An 84-year-old female visited her local clinic due to right abdominal pain that had lasted for 3 days. Ultrasonography revealed a gallbladder stone and the gallbladder swelling. Accordingly, she was referred to our hospital, where we detected a 5 -cm stone impacted in the gallbladder neck on imaging, and we admitted the patient with a diagnosis of acute cholecystitis. As it was difficult to secure a puncture route for percutaneous transhepatic gallbladder drainage we performed endoscopic retrograde cholangiopancreatography to place EGBS through the papilla. The patient progressed favorably after the procedure and was discharged on hospital day 10. Although the patient was followed up without cholecystectomy, 3 months later, she was transported to the hospital by ambulance with abdominal pain and vomiting. A CT scan revealed that the gallbladder stent had fallen into the ileocecal region and a gallstone was impacted in the ileum, causing gallstone ileus. After admission, we initiated treatment by placing an ileus tube and removed the gallstone by ileotomy after the ileus improved. The patient progressed well postoperatively and was discharged on hospital day 42 of the second hospitalization.

Department of Gastroenterology, Chiba Kaihin Municipal Hospital

*Corresponding author : shinichi.tazawa24@gmail.com 